DZIEJE NAJNOWSZE, ROCZNIK XLVII - 2015, 4

PL ISSN 0419-8824

Tomasz Kozłowski

Warszawa

\title{
Polityczne sterowanie systemem wymiaru sprawiedliwości PRL po 1956 r. Casus funkcjonowania „zespołów” do spraw procesów politycznych w latach 1964-1982*
}

W 1982 r., w czasie trwania stanu wojennego, prokuratura wytoczyła sprawę karną członkom KSS-,,KOR”. Po podaniu tej informacji do publicznej wiadomości Aniela Steinsbergowa napisała: „Jeśli dojdzie do wniesienia aktu oskarżenia, to proces ten będzie figurował wśród szeregu sfingowanych procesów, które odbywały się na różnych etapach historii PRL i stanowią jedną z najciemniejszych kart tej historii”. Steinsbergowa zwracała uwagę, że chociaż polityczne oskarżenia nie miały już takiego charakteru jak w latach stalinowskich, to jednak ,nosiły również to samo piętno procesów fabrykowanych dla doraźnych celów politycznych"'.

Jej potwierdzone wieloletnimi doświadczeniami obserwacje były trafne. W ramach funkcjonującego po 1956 r. systemu wymiaru sprawiedliwości władze przede wszystkim kształtowały politykę karną, nie zrezygnowały jednak z wpływania na przebieg poszczególnych procesów, istotnych z politycznego punktu widzenia. Istnienie mechanizmów nacisku na sądownictwo jest zazwyczaj trudne do udowodnienia, ślady zachowane w dokumentach można odnaleźć bardzo rzadko. Przedstawione w artykule ustalenia opierają się na efektach kwerendy w dokumentacji Komitetu Centralnego PZPR, Prokuratury Generalnej PRL, Ministerstwa Sprawiedliwości, MSW oraz SB. Na podstawie zachowanych materiałów można prześledzić wpływ władz partyjnych na przebieg procesu w przypadku kilku najgłośniejszych spraw politycznych: Kuronia i Modzelewskiego, „Komandosów”, „Taterników”, organizacji „Ruch”, KSS-KOR, KPN oraz tzw. Jedenastki, czyli kierownictwa „Solidarności” oraz czołowych doradców związku z kręgów opozycji demokratycznej.

We wszystkich wymienionych sprawach można odnaleźć pewne prawidłowości. Pierwszym ogniwem, zajmującym się dokumentowaniem i badaniem danego przestępstwa, były organy policyjne oraz prokuratura. Syntetyczne wnioski z ich pracy przedstawiano osobom z odpowiednich wydziałów KC lub Biura Politycznego. O ostatecznej formie dalszych działań, wniesieniu oskarżenia lub jego zaniechaniu decydowano w czasie spotkań w nielicz-

\footnotetext{
* Artykuł powstał w ramach Centralnego Projektu Badawczego Biura Edukacji Publicznej IPN „Struktury i działalność Polskiej Zjednoczonej Partii Robotniczej” kierowanego przez prof. Jerzego Eislera.

${ }^{1}$ A. Steinsbergowa, Proces KSS-KOR, refleksje i analogie, Warszawa 1983, s. 3, 4.
} 
nym gremium, które często określano mianem ,zespołu”. Brali w nim udział przedstawiciele prokuratury, MSW, Wydziału Administracyjnego KC, a często także osoby z Ministerstwa Sprawiedliwości czy nawet Sądu Najwyższego. Wiele wskazuje na to, że takie rozwiązania funkcjonowały przez wiele lat.

Wprowadzenie takiego mechanizmu wiązało się najprawdopodobniej z problemami, jakie władze napotykały przy eskalacji procesów w sprawach gospodarczych i próbie propagandowego wykorzystania tzw. afery mięsnej, w czasie której za kradzieże i nadużycia związane $\mathrm{z}$ obrotem tym towarem w Warszawie aresztowano kilkaset osób. Po błyskawicznym procesie cztery z nich skazano na dożywocie, a Stanisława Wawrzeckiego na karę śmierci. Po czterdziestu latach Sąd Najwyższy III RP uchylił ten wyrok, wyrażając nadzieję, że posłuży to „częściowej rehabilitacji wymiaru sprawiedliwości [...] który przed laty nie zapewnił oskarżonym tego, co w dniu dzisiejszym [...] nazwać należy «rzetelnym procesem», a co, używając zwykłej i nader tradycyjnej nomenklatury, określić trzeba procesem sprawiedliwym"”.

„Afera mięsna" stanowiła apogeum fali procesów prowadzonych od końca lat pięćdziesiątych do początku lat siedemdziesiątych w sprawach o przestępstwa gospodarcze. Po przełomie 1956 r. stopniowo rozbudzał się apetyt konsumpcyjny społeczeństwa. Nie brakowało osób, które w niedomagającym i patologicznym systemie znalazły przestrzeń na prowadzenie półlegalnych i nielegalnych interesów. Władze nie były w stanie naprawić gospodarki, ale mogły sięgnąć po straszaka w postaci represji i wskazać społeczeństwu kozły ofiarne. W styczniu 1959 r. odbyło się posiedzenie Biura Politycznego z gościnnym udziałem ministra sprawiedliwości, prokuratora generalnego, ministra spraw wewnętrznych i prezesa Sądu Najwyższego. Upomniano ich za „opieszałość, liberalizm, a nawet tolerancyjny stosunek niektórych sędziów i prokuratorów wobec winnych przestępstw gospodarczych”. Kierownictwo partyjne zaleciło natychmiastowe zmiany.

Surowe kary dla ludzi zamieszanych w liczne afery: skórzaną, nasienniczą, piekarską czy mięsną, służyły nie tylko „wymierzeniu sprawiedliwości”. Miały także stanowić przestrogę. W 1959 r. na ławę oskarżonych trafił dyrektor Warszawskich Zakładów Garbarskich Eugeniusz Galicki. Ku niezadowoleniu kierownictwa partyjnego został skazany tylko na dożywocie. Minister sprawiedliwości Marian Rybicki twierdził, że był to efekt „załamania się” sędziego Michała Kulczyckiego, który za nieposłuszeństwo zapłacił stanowiskiem. W $1960 \mathrm{r}$. Sąd Wojewódzki w Kielcach za kradzież skór w spółdzielniach garbarskich w Radomiu i Szydłowcu skazał na karę śmierci Bolesława Dedę. Wyciągnięto lekcje z poprzednich niepowodzeń. Minister Rybicki obiecał, że proces nie będzie przewlekany, a skład sędziowski skonsultowano z Komitetem Wojewódzkim w Kielcach. Tym razem z szeregu wyłamał się jednak prokurator generalny Andrzej Burda, który w marcu 1961 r. wystąpił do Rady Państwa o ułaskawienie skazanego. Podobnie jak sędzia Kulczycki on także stracił stanowisko. W sprawie ułaskawienia wybuchła sprzeczka między przewodniczącym Rady Państwa Aleksandrem Zawadzkim a Gomułką, który kategorycznie zażądał podtrzymania wyroku śmierci. Zawadzki miał inne zdanie, odburknął Gomułce: „Jak chcesz, to możesz sam kazać się wybrać na przewodniczącego Rady Państwa, wtedy będziesz podpisywać [wyroki śmierci]”3.

Aby nie dopuścić do podobnych sytuacji w procesie „afery mięsnej”, zwołano naradę, w której wzięli udział przedstawiciele Sądu Najwyższego, Prokuratury Generalnej oraz Wydziału Administracyjnego KC PZPR. Zgodnie z notatką zastępcy prokuratora generalne-

\footnotetext{
${ }^{2}$ Wyrok Sądu Najwyższego z 27 VII 2004 r. (II KK 332/03).

3 D. Jarosz, M. Pasztor, Afera mięsna. Fakty i konteksty, Toruń 2004, s. 261-263, 270-274; P. Chojnacki, K. Madej, Przypadki prokuratora, „Biuletyn Instytutu Pamięci Narodowej” 2005, nr 1-2, s. 115120.
} 
go, odnalezioną przez badającego sprawę Krzysztofa Madeja, spotkanie miało mieć „doniosły wpływ na sposób merytorycznego zakończenia toczącego się śledztwa oraz na treść wyroku sądowego, jaki zapadnie w tej sprawie”“4. Wydaje się, że właśnie te sprawy gospodarcze, w szczególności ,afera mięsna”, dały początek nowemu modelowi działania, który przez lata stosowano w procesach o szczególnym znaczeniu politycznym.

\section{Przykłady działalności ,zespołów”}

Pod koniec 1964 r. o sprawie Jacka Kuronia i Karola Modzelewskiego dyskutowano na spotkaniu członka Biura Politycznego i sekretarza KC Ryszarda Strzeleckiego, szefa MSW Władysława Wichy i jego zastępcy Mieczysława Moczara oraz przedstawiciela Prokuratury Generalnej. Ostatecznie nie zdecydowano się na wniesienie oskarżenia ze względu na to, że „zostały podjęte ustalenia z udziałem sekretarzy KC i kier[ownictwa] MSW”. W późniejszym okresie organa polityczne, w tym przypadku Sekretariat KC, decydowały m.in. w sprawie liczby procesów, które miały dojść do skutku . W przypadku sprawy „Komandosów” znamy przykład posiedzenia ,zespołu” do spraw politycznych. Miało ono miejsce 29 XI $1968 \mathrm{r}$. u sekretarza KC Mieczysława Moczara z udziałem prokuratora generalnego PRL Kazimierza Kosztirki i jego zastępcy Henryka Cieśluka oraz ministra sprawiedliwości Stanisława Walczaka i podsekretarza stanu w Ministerstwie Sprawiedliwości Franciszka Ruska. W czasie spotkania dyskutowano, kiedy rozpocząć proces, jak długo powinien trwać oraz w ilu grupach sądzić oskarżonych. W tym samym czasie omawiano także inną głośną sprawę polityczną - frakcyjnej Komunistycznej Partii Polski, kierowanej przez Kazimierza Mijala ${ }^{6}$. Nie było to zapewne jedyne posiedzenie zespołu zajmującego się tymi konkretnymi sprawami. Problem polega na tym, że często spotkania takie nie były protokołowane. Odręcznie zapisano, w nieczytelnej formie, informacje o ustaleniach poczynionych w grudniu $1968 \mathrm{r}$. na spotkaniach z uczestnictwem nowego przewodniczącego Wydziału Administracyjnego KC Stanisława Kani. Można z nich wywnioskować, że omawiał on sprawę oskarżenia „Komandosów” w ramach ,zespołu”, w którego skład wchodzili m.in. minister sprawiedliwości oraz prokurator generalny ${ }^{7}$.

Zachowały się także dokumenty dotyczące prac zespołu obradującego w 1969 r. nad losem „Taterników”, czyli współpracowników paryskiej „Kultury” zaangażowanych w przemyt wydawnictw emigracyjnych. Na ich podstawie można stwierdzić, że prokurator generalny Kazimierz Kosztirko informował szefa MSW Kazimierza Świtałę o spotkaniu, w czasie którego omawiano m.in. termin rozpoczęcia prac sądu oraz podjęto decyzję, że „,w przypadku złożenia do sądu wniosków o uchylenie aresztu tymczasowego wobec [...] oskarżonych, wnioski takie należałoby uwzględnić". Rozmawiano więc także o kwestiach znajdujących się w bezpośredniej gestii składu sędziowskiego. Jak ustalił Bartosz Kaliski, w skład ,zespołu” wszedł kierownik Wydziału Administracyjnego Stanisław Kania, sekretarz Komitetu Warszawskiego PZPR Jerzy Łukaszewicz, minister sprawiedliwości Jerzy Walczak, prokurator generalny Kazimierz Kosztirko, prezes Izby Karnej SN Franciszek Wróblewski oraz przedstawiciele MSW. Dzięki notatce wicedyrektora Biura Śledczego wiemy, iż w styczniu 1970 r. Kania przekonywał pozostałych, że efekt odstraszający już osiągnięto dzięki długotrwałym aresztom i proces nie jest konieczny. Zaproponował zwolnienie „Taterników”,

\footnotetext{
${ }^{4}$ K. Madej, Kara śmierci za mięso, ibidem, 2002, nr 11, s. 55-60.

${ }^{5}$ A. Friszke, Anatomia buntu. Kuroń, Modzelewski i komandosi, Kraków 2010, s. 187, 188, 257, 749.

${ }^{6}$ AAN, KC PZPR, LI/22, Notatka o ustaleniach poczynionych na konferencji w dniu 29 XI 1968 r., b.p.

${ }^{7}$ Ibidem, Odręczna notatka na temat spotkania 4 XII 1968 r., b.p.
} 
czemu jednak sprzeciwił się minister sprawiedliwości. Przekonywał, że „sprawa zaszła zbyt daleko”. Twierdził, że z sytuacji „trzeba wyjść z twarzą” — przeprowadzić postępowanie do końca i dopiero wtedy zastosować amnestię. Poinformował, że w sprawie zapadną wyroki od dwóch do czterech lat. Nie mogło być mowy o jakichś nieprzewidzianych okolicznościach. Zapewnił o tym prezes Wróblewski: „«Ulgowe» traktowanie tego typu spraw wpływa demoralizująco na sędziów"

$\mathrm{Na}$ początku lat siedemdziesiątych podobną praktykę spotkamy w sprawie przeciwko działaczom organizacji „Ruch”. Mniej więcej w maju 1971 r., kiedy śledztwo wchodziło w końcową fazę, odbyło się spotkanie w Wydziale Administracyjnym KC PZPR. Oprócz działaczy z ramienia KC PZPR pojawiło się na spotkaniu kierownictwo MSW oraz delegacje z Ministerstwa Sprawiedliwości, Sądu Najwyższego i Prokuratury Generalnej. Na spotkaniu „omówiono propozycje Prokuratora Generalnego i MSW co do sposobu zakończenia postępowania przygotowawczego". Zadecydowano o rezygnacji z oskarżenia części osób, aby nie nadawać większego rozgłosu, niż to absolutnie konieczne. Ze wszystkich, przeciwko którym zebrano dowody, oskarżona miała zostać mniej niż połowa. Te trzydzieści trzy osoby planowano osądzić w sześciu oddzielnych procesach ${ }^{9}$.

Podobny mechanizm wpływania na kierunek pracy, tym razem kolegiów, widoczny był w 1976 r. w sprawach wobec protestujących robotników. 27 czerwca wiceminister spraw wewnętrznych i kierownik sztabu „Lato-76” gen. Bogusław Stachura wraz z dyrektorem Biura Śledczego MSW płk. Tadeuszem Kwiatkowskim spotkali się w budynku KC PZPR ze Stanisławem Kanią oraz ministrem sprawiedliwości Jerzym Bafią i prokuratorem generalnym PRL Lucjanem Czubińskim. Kania wydał polecenie, aby orzeczenia sądowe i kolegium były poddawane weryfikacji przez prokuratury i sądy, a w wyniku tego także zaostrzane. Polecenia te zostały wdrożone w życie ${ }^{10}$.

Podobny schemat działania stosowano w drugiej połowie lat siedemdziesiątych w sprawie Komitetu Obrony Robotników. Kierownictwo partyjne było podzielone w kwestii działań, jakie trzeba było podjąć wobec KOR. Część, z wiceministrem Bogusławem Stachurą na czele, uważała, że należy przeprowadzić silne uderzenie w Komitet. Druga grupa, w której najważniejszą osobą był Stanisław Kania, chciała walczyć z opozycją środkami „miękkimi”. Jak zauważył Andrzej Friszke: „Problem opozycji nigdy nie był dyskutowany na posiedzeniach statutowych gremiów PZPR - Biura Politycznego lub Sekretariatu KC — ale rozmawiano o nim na nieformalnych spotkaniach i w węższych gronach" ". Spotkania takie odbywały się np. w gabinecie Stanisława Kani. Zaproszeni byli ludzie z kierownictwa partyjnego, MSW i Prokuratury Generalnej ${ }^{12}$. Kania, który toczył z częścią kierownictwa spór o skalę represji wobec opozycji demokratycznej, doprowadził do utworzenia nieformalnego zespołu, którego pierwsze spotkanie odbyło się w marcu 1978 r. Nie został on wyłoniony ani

\footnotetext{
${ }^{8}$ B. Kaliski, Kurierzy wolnego stowa. Paryż - Praga - Londyn 1968-1970, Warszawa 2014, s. 307, 308; AIPN BU 0582/20/DVD, t. 9, Pismo prokuratora generalnego Kazimierza Kosztirko do ministra spraw wewnętrznych Kazimierza Świtały w sprawie narady 10 X 1969, 27 X 1969 r., k. 44-47; ibidem, Notatka służbowa z narady w Wydziale Administracyjnym KC PZPR, 14 I 1970 r., k. 155-158.

${ }_{9}$ AAN, LI/22, Notatka o ustaleniach i propozycjach zakończenia śledztwa w sprawie nielegalnej organizacji pod nazwą „Ruch”, maj 1971 r., b.p.

${ }_{10}$ P. Sasanka, Czerwiec 1976. Geneza, przebieg, konsekwencje, Warszawa 2006, s. 283-285.

${ }^{11}$ Rozmowy na Zawracie. Taktyka walki z opozycja demokratyczna październik 1976-grudzień 1979, przedmowa i opracowanie: A. Friszke, wybór: A. Friszke, M. Zaremba, Warszawa 2008, s. 15.

${ }^{12}$ Przykład notatki z takiego posiedzenia opublikowano na łamach „Więzi”: „Zawężona represja”. Co zrobić z Komitetem Obrony Robotników? Narada u Stanisława Kani 22 października 1976, oprac. A. Paczkowski, M. Zaremba, „Więź” 2001, nr 8.
} 
przez Sekretariat KC, ani przez Biuro Polityczne. Jego skład był zmienny, ale w grupie zawsze znajdowali się przedstawiciele wydziałów $\mathrm{KC}$, których interesowały kwestie opozycji demokratycznej, reprezentant kierownictwa MSW i odpowiedniego departamentu SB oraz wysłannik Prokuratury Generalnej ${ }^{13}$. W tym gronie dyskutowano, co zrobić z działaczami opozycji: aresztować czy pozostawić na wolności, sądzić czy nie sądzić, prześladować czy zostawić w spokoju. Nie było to więc działanie nakierowane ściśle na przygotowanie procesu politycznego, ale na całokształt działań, także represyjnych.

Kolejnym przykładem ręcznego sterowania sprawą przez powołany „zespół” jest proces działaczy Konfederacji Polski Niepodległej. Sygnał do podjęcia zdecydowanych środków przeciwko konfederatom wyszedł 17 IX 1980 r. z Biura Politycznego KC PZPR: „Powinno [się odpowiedzieć] na podstawie pełnego rozeznania i chłodnej kalkulacji, czy można zaostrzyć represje, biorąc pod uwagę wszystkie reperkusje wewnętrzne i zewnętrzne" "14. Dzień później MSW rozpoczęło pracę nad podjęciem prawnych kroków przeciwko Leszkowi Moczulskiemu ${ }^{15}$. W oparciu o treść wywiadu udzielonego przez Moczulskiego dla zagranicznej gazety planowano postawić zarzuty z art. 133 - publicznego nawoływania do czynów skierowanych przeciwko jedności sojuszniczej PRL (za wypowiedź o możliwości wystąpienie Polski z Układu Warszawskiego) oraz z art. 270 - poniżanie naczelnych organów PRL (za passus dotyczący ,kierownictwa polskiego, którego nie można określić ani jako kierownictwo, ani jako polskie"). O tej sprawie rozmawiano 20 września w czasie posiedzenia kierownictwa $\mathrm{MSW}^{16}$.

Zielone światło dla operacji dał minister Stanisław Kowalczyk. Tutaj jednak zaczęły się problemy - po raz pierwszy zanotowano tak wyraźny przypadek sprzeciwu ze strony sędziów. Sędzia Krzysztof Janiszewski z Wydziału VII Karnego Sądu Rejonowego dla m. st. Warszawy wyłączył się od rozpoznania zażalenia Leszka Moczulskiego na postanowienie o tymczasowym aresztowaniu. Z naczelnikiem Wydziału Śledczego Wiesławą Bardonową skontaktował się przewodniczący Wydziału VII Piotr Aleksandrow i oświadczył, że „nie ma w Wydziale sędziego, który by wydał w tej sprawie postanowienie utrzymujące areszt tymczasowy w mocy”. Sędziowie z Wydziału VII wyrażali opinię, że „ktokolwiek z sędziów otrzymałby na dyżurze tę sprawę do rozpoznania, nie podjąłby takiej decyzji”, ${ }^{17}$. Ostatecznie decyzję musiał podtrzymać w mocy sam przewodniczący Wydziału. Taka sytuacja — zdecydowanego sprzeciwu ze strony sędziów — była wyjątkowa.

Był to znak nowych czasów. Proces KPN od samego początku nie był prowadzony po myśli władz partyjnych i państwowych. Rozpoczął się w Sądzie Wojewódzkim w Warszawie w czerwcu, tymczasem już w sierpniu Biuro Śledcze zaczęło się ,skarżyć” na powolne i nieprofesjonalne prowadzenie sprawy. Zdaniem Biura odpowiedzialność za to ponosiło „wyznaczenie na przewodniczącego składu sądzącego Cz[esława] Szabłowskiego, który — na co wskazuje szereg przesłanek - nie dawał gwarancji prawidłowego rozpoznania sprawy". O tym, że był to sędzia niegodny zaufania, świadczyć miało m.in. uchylenie tymczasowego aresztu oskarżonych. Błąd skorygowano - nowym przewodniczącym zespołu orzekającego

\footnotetext{
${ }_{13}$ Rozmowy na Zawracie, s. 23.

${ }^{14}$ Protokót nr 32 z posiedzenia Biura Politycznego KC PZPR 17 września 1980 r., w: PZPR a ,, Solidarnośc” 1980-1981. Tajne dokumenty Biura Politycznego, wstęp T. Kozłowski, Warszawa 2013, s. 175.

${ }^{15}$ AIPN, BU 0365/66, t. 7, Notatka dotycząca spodziewanych implikacji w związku z aresztowaniem Leszka Moczulskiego, k. 64-65; AIPN, BU 1585/198, Ocena prawno-karna treści wywiadu Leszka Moczulskiego udzielonego Der Spiegel, 18 IX 1980, k. 27-28.

16 AIPN, BU 1585/198, Protokół z posiedzenia kierownictwa MSW 20 IX 1980, k. 29-30.

${ }^{17}$ AAN, Prokuratura Generalna PRL, 37/80, Notatka służbowa Wiesławy Bardonowej w sprawie przeciwko Leszkowi Moczulskiemu, k. 53.
} 
w sprawie KPN został wiceprezes Sądu Wojewódzkiego w Warszawie Janusz Jankowski. Mimo to, zdaniem Biura Śledczego, nadal nie nastąpiła radykalna zmiana sposobu prowadzenia procesu: „sąd nie reaguje na prowokacyjne wnioski ze strony obrońców [...] nie reaguje we właściwy sposób na prowokacyjne wnioski oskarżonych [...] nie reaguje na oświadczenia L[eszka] Moczulskiego, wykraczające poza ramy obrony i nie związane z przedmiotem rozprawy sądowej”. Co więcej, sędzia usunął z sali rozpraw inspektora śledczego MSW, który „Śledził proces sporządzając notatki z jego przebiegu" ${ }^{\prime 18}$.

Taki tryb prowadzenia sprawy KPN był nie do zaakceptowania dla władz partyjnych, zwłaszcza że od kilkunastu tygodni kwestię tę poruszano w czasie spotkań i rozmów międzynarodowych, m.in. z przedstawicielami sowieckiego Politbiura. I sekretarz KC PZPR Stanisław Kania był w tej sprawie indagowany w lipcu 1981 r. przez Breżniewa, który nie krył zaskoczenia z powodu zwolnienia Moczulskiego i nalegał na szybkie zakończenie sprawy. Kania tłumaczył, że „Moczulski został zwolniony z inicjatywy własnej sądu [a nie władz partyjnych]. Zareagowaliśmy — zmieniony został minister i komplet sędziowski”. Sprawa znajdowała się cały czas pod szczególnym nadzorem. W sierpniu gen. Mirosław Milewski informował Biuro Polityczne, że „w toku procesu KPN wywierana jest presja na sąd"19.

18 IX 1981 r. w czasie posiedzenia kierownictwa MSW Czesław Kiszczak thumaczył: „Istotne byłyby dla Premiera [Wojciecha Jaruzelskiego] takie [szczegółowe] dane związane z procesem KPN, które pozwalałyby na niezwłoczną rozmowę z Ministrem Sprawiedliwości i zwrócenie uwagi, że resort ten we wskazanej sprawie winien przejawiać bardziej czynną postawę lub podjąć określone działania"20. Sięgnięto do starych sprawdzonych wzorców i powołano „zespół” do sprawy KPN. Spotkał się on 24 listopada pod przewodnictwem gen. Mirosława Milewskiego. Wzięły w nim udział następujące osoby: kierownik Wydziału Organizacyjnego KC PZPR Kazimierz Cypryniak i kierownik Wydziału Administracyjnego KC PZPR Michał Atłas, prokurator generalny Franciszek Rusek i jego zastępca Józef Żyta, wiceminister spraw wewnętrznych Władysław Ciastoń, zastępca dyrektora Departamentu III MSW Mieczysław Kowalski, wiceminister sprawiedliwości Tadeusz Skóra i dwaj zastępcy wydziałów KC. Postanowiono m.in. że „Ministerstwo Sprawiedliwości przygotuje i przedstawi koncepcję usprawnienia i przyśpieszenia pracy sądu, celem jak najszybszego doprowadzenia do końca rozprawy sądowej przeciwko przywódcom KPN"21. W projekcie tym przewidziano wystosowanie oficjalnej uwagi do prezesa Sądu Wojewódzkiego w Warszawie w sprawie nieprawidłowości. W przypadku nieskuteczności tego kroku planowano udzielić „wytyku” składowi sędziowskiemu, tzn. upomnienia, m.in. za „tolerowanie znieważania i obrażania przez oskarżonych ustroju, partii, władz państwa, prokuratury i wymiaru sprawiedliwości"22. Następne posiedzenie zespołu miało się odbyć sześć dni później, jednak informacji o jego przebiegu nie udało się odnaleźć. Ostatecznie proces działaczy KPN udało się odpowiednio ukierunkować dopiero w czasie stanu wojennego przy wsparciu ze strony Sądu Najwyższego.

\footnotetext{
${ }^{18}$ Ibidem, 3/367, Notatka zawierająca uwagi na tle procesu przeciwko R. L. Moczulskiemu i innym członkom kierownictwa KPN, 25 VIII 1981, k. 102-108.

${ }_{19}$ Protokót nr 2 z posiedzenia Biura Politycznego KC PZPR 1 sierpnia $1981 \mathrm{r}$, w: PZPR a „Solidarność” 1980-1981. Tajne dokumenty Biura Politycznego, wstęp T. Kozłowski, Warszawa 2013, s. 641. Zob. też: Protokót nr 102 z posiedzenia Biura Politycznego KC PZPR 7 lipca 1981 r., ibidem, s. 625629.

${ }^{20}$ AIPN, BU 1585/202, Protokół z posiedzenia kierownictwa MSW w dniu 18 IX 1981, k. 3.

${ }^{21}$ AAN, KC PZPR, LI/39, Notatka w sprawie zintensyfikowania działań przeciwko KPN w dniu 24 XI 1981, 25 XI 1981, b.p.

${ }^{22}$ Ibidem, Plan przeciwdziałam niewłaściwemu prowadzeniu rozprawy w sprawie karnej L. Moczulskiego i trzech innych oskarżonych, b.d., b.p.
} 
W 1982 r. powołano kolejny ,zespół” do przygotowania kluczowego z punktu propagandy procesu politycznego - grupy przywódców „Solidarności” oraz działaczy opozycji demokratycznej ${ }^{23}$. Na ławie oskarżonych znaleźli się: Jacek Kuroń, Jan Lityński, Adam Michnik, Henryk Wujec oraz Andrzej Gwiazda, Seweryn Jaworski, Marian Jurczyk, Karol Modzelewski, Grzegorz Palka, Andrzej Rozpłochowski i Jan Rulewski² . Na szybkie zakończenie sprawy naciskał urzędujący premier i I sekretarz KC PZPR - Wojciech Jaruzelski. Jego rozkazy przekazał kierownictwu organów ścigania Czesław Kiszczak: „Zadanie zlecone przez Premiera, to proces Kuronia i jego wspólników, za działalność antypaństwową. Muszą się tym zająć wszystkie jednostki operacyjne SB, a głównie Biuro Śledcze"25. Większości oskarżonych planowano wytoczyć proces z artykułu 123 kodeksu karnego: „Kto, mając na celu pozbawienie niepodległości, oderwanie części terytorium, obalenie przemocą ustroju lub osłabienie mocy obronnej Polskiej Rzeczypospolitej Ludowej podejmuje w porozumieniu z innymi osobami działalność zmierzającą do urzeczywistnienia tego celu, podlega karze pozbawienia wolności na czas nie krótszy od lat 5 albo karze śmierci”. Dopuszczano także możliwość oskarżenia z art. 128 kk, czyli usiłowania dokonania przestępstwa z art. 123 kk.

$\mathrm{Na}$ czele ,zespołu” stanął członek Biura Politycznego i sekretarz KC PZPR Mirosław Milewski. Ten były minister spraw wewnętrznych, powszechnie zaliczany do partyjnego „,betonu", był zwolennikiem nasilenia represji. Z ramienia organizującego spotkanie Wydziału Administracyjnego KC pojawił się jego kierownik Michał Atłas wraz ze swoim zastępcą Wiktorem Grzelcem. Obok niego w spotkaniu uczestniczyli Czesław Kiszczak, dyrektor Biura Śledczego Hipolit Starszak, zastępca prokuratora generalnego i naczelny prokurator wojskowy Józef Szewczyk, prezes Izby Wojskowej Sądu Najwyższego Kazimierz Lipiński, prezes Izby Karnej Sądu Najwyższego Bogdan Dzięcioł oraz prokurator generalny Franciszek Rusek. Zebrani razem w jednym pokoju mieli wpływ na kształt aktu oskarżenia, termin rozpoczęcia procesów oraz, można założyć z dużym prawdopodobieństwem, na wynik sprawy sądowej. Politycy, prokuratorzy i sędziowie w czasie tego spotkania ustalili ostatecznie, że wkrótce rozpoczną się nowe procesy w sprawie KSS-KOR i kierownictwa „Solidarności”. Przede wszystkim, za sugestią Kiszczaka, zrezygnowali z postawienia zarzutów w sierpniu — głównie z powodu obaw przed niezadowoleniem społecznym. Tymczasowa Komisja Koordynacyjna, czyli podziemne kierownictwo ,Solidarności”, wezwała do organizowania w tym miesiącu strajków ${ }^{26}$.

Dla ustalenia terminu procesu ważny był jeszcze jeden czynnik. Mirosław Milewski zwracał uwagę, że ,zbliża się termin rozpoczęcia pracy przez Trybunał Stanu”. Pod koniec grudnia 1981 r. Jaruzelski jako przewodniczący WRON wystąpił do marszałka Sejmu o określenie ,odpowiedzialności osób winnych doprowadzenia Państwa w latach siedemdziesiątych do głębokiego kryzysu". Posunięcie to było w dużym stopniu podyktowane potrzebą obciążenia dawnego kierownictwa partyjnego za zły stan gospodarki — planowano pociągnąć

\footnotetext{
${ }^{23}$ Notatki dotyczące działalności zespołu pod kierownictwem członka Biura Politycznego i sekretarza KC PZPR Mirosława Milewskiego oraz krótkie wprowadzenie w T. Kozłowski, ,, $W$ tym procesie nie będzie wyroków śmierci”. Taktyka oskarżenia działaczy KSS-KOR i „, Solidarności” w 1982 r., „Więź” 2012, nr 11/12, s. 109-124. O politycznych aspektach przygotowywanego oskarżenia i reakcji oskarżonych zob. J. Skórzyński, Odrzucona propozycja. Rozmowy o uwolnieniu przywódców Solidarności 1983-1984, „Wolność i Solidarność. Studia z dziejów opozycji wobec komunizmu i dyktatury” 2012, nr 4, s. 104-112.

${ }^{24}$ O historii ,jedenastki” zob.: A. Friszke, Tymczasowa Komisja Koordynacyjna NSZZ „, Solidarność” (1982-1987), w: Solidarność podziemna 1981-1989, red. A. Friszke, Warszawa 2006, s. 87-91.

${ }_{25}$ AIPN, BU 1585/203, Protokół z posiedzenia kierownictwa MSW w dniu 18 I 1982, k. 57.

${ }^{26}$ Zob.: Dokumenty władz NSZZ ,, Solidarnośc” 1981-1989, wstęp, wybór i oprac. J. Olaszek, Warszawa 2010 , s. 78 . W protestach wzięło udział co najmniej 118 tys. osób w całym kraju.
} 
do odpowiedzialności m.in. Edwarda Gierka, Piotra Jaroszewicza, Tadeusza Wrzaszczyka, Jana Szydlaka i Tadeusza Pykę. Połączenie terminu procesów miało stworzyć wrażenie symetrii. Uderzenia z jednej strony w „siły antysocjalistyczne” (KSS-,,KOR”), „ekstremę” (kierownictwo „Solidarności”) i ,prominentów” (część tzw. ekipy Gierka rządzącej w latach siedemdziesiatych).

Jeszcze na początku 1982 r. Czesław Kiszczak twierdził, uzgodniwszy to zapewne z Wojciechem Jaruzelskim, że ,przed Trybunałem Stanu obok «prominentów» winni stanąć także niektórzy działacze i doradcy «Solidarności»"27. Kilka dni wcześniej, 24 XII 1981 r., członek Biura Politycznego Stefan Olszowski stwierdził, że należy powołać Trybunał Stanu dla osądzenia byłego kierownictwa PZPR, a „kiedyś trzeba będzie może sądzić i Wałęsę”28. Potrzeba symetrii w tej sprawie był tak duża, że gdy w marcu 1982 r. na jednym z posiedzeń kierownictwa resortu spraw wewnętrznych dyrektor Zarządu Polityczno-Wychowawczego MSW gen. Edward Tarała spytał, czemu nie doszło jeszcze do procesu byłego kierownictwa PZPR, wiceminister spraw wewnętrznych gen. Bogusław Stachura odpowiedział, że „Gierek nie staje przed sądem, bo Wałęsa też jeszcze nie staje" ${ }^{, 29}$. Z drugiej strony w czasie posiedzenia Biura Politycznego Wojciech Jaruzelski stanowczo protestował przeciwko nadawaniu podobnej wagi obu sprawom. Na uwagę Albina Siwaka: „Trybunał Stanu ma rozliczać byłych prominentów [...] ale nie mówi się o rozliczeniu ekstremy Solidarności”, Jaruzelski odparł: „Trybunał Stanu to organ polityczny i nie ten organ będzie sądził za odpowiedzialność polityczną Gierka i [jednocześnie] takich przestępców jak Kuroń”. Nie zmienia to jednak faktu, że takie symetryczne uderzenie w obie grupy było zaplanowanym zabiegiem politycznym i socjotechnicznym.

O ile proces ,,prominentów” był przygotowywany powoli, o tyle 19 VIII 1982 r. na spotkaniu ,zespołu” do sprawy ,jedenastki” podjęto decyzję, aby najpierw rozpocząć proces KSSKOR, który miał być „,papierkiem lakmusowym” — w razie niezbyt energicznej reakcji opinii publicznej i opozycji demokratycznej planowano w drugiej kolejności zająć się także kierownictwem „Solidarności”. W czasie posiedzenia ustalono sposób przeprowadzenia postępowania dowodowego. Ponieważ proces podporządkowany był logice działania politycznego, Mirosław Milewski nalegał, aby nie wikłać się w skomplikowaną sprawę, tak aby można było wydać szybki wyrok: ,nie należy dążyć do uzyskania «wielkich dowodów» [...] wykorzystać należy artykuły Michnika i Kuronia zamieszczone w prasie zagranicznej [...] można oczekiwać wyroku skazującego na 3-4 lata pozbawienia wolności [...] Nie powinno być tasiemcowych zarzutów. W procesie tym nie będzie wyroków śmierci; nadmierna ilość orzeczonych lat pozbawienia wolności też nie jest najważniejsza". Przedstawiciele MSW oraz prokuratorzy byli zgodni, że ze względu na wyjątkowość sprawy należy skierować do niej najlepszych ludzi. Z wnioskiem zgodził się Mirosław Milewski: „Do spraw tych skierować należy najlepszych prokuratorów i sędziów. Źle byłoby, gdyby zarzuty miały upadać w czasie procesu”. Oświadczył on także, że przynajmniej chwilowo odroczone będzie oskarżenie Wałęsy ${ }^{30}$.

\section{Mechanizmy ręcznego sterowania}

Jedno z zasadniczych pytań brzmi: Czy ustalenia „zespołów”, w których skład wchodzili przedstawiciele MSW, Prokuratury, Wydziału Administracyjnego KC, Sądu Najwyższego oraz Ministerstwa Sprawiedliwości, miały przełożenie nie tylko, co bezsprzeczne, na kształt

\footnotetext{
${ }^{27}$ AIPN, BU 1585/203, Protokół z posiedzenia kierownictwa MSW w dniu 18 I 1982, k. 59.

${ }^{28}$ M. F. Rakowski, Dzienniki polityczne 1981-1983, Warszawa 2004, s. 147.

${ }^{29}$ AIPN, BU 1585/203, Protokół z posiedzenia kierownictwa MSW w dniu 15 III 1982, k. 83.

${ }^{30}$ T. Kozłowski, ,, W tym procesie nie będzie wyroków śmierci”, s. 109-124.
} 
aktu oskarżenia, ale także na postawę sędziów i wydawane wyroki? Nie można mieć całkowitej pewności, jednak opierając się na poszlakach, można zaryzykować twierdzenie, że tak właśnie było. W praktyce system ten mógł działać dzięki współpracy władz partyjnych z Sądem Najwyższym oraz Ministerstwem Sprawiedliwości. To one miały stać na straży prawidłowej pracy sędziów. Prezesury, stanowiska kierownicze w sądach wyższych instancji oraz w Sądzie Najwyższym były objęte systemem nomenklatury. Znaczyło to, że pozycja zawodowa sędziów zależała od opinii środowiska partyjnego lub w przypadku wyższych stanowisk także od odpowiedniego wydziału KC PZPR - w tym przypadku Administracyjnego. Tego samego, którego kierownik wchodził często w skład ,zespołów” do spraw procesów politycznych.

Zgodnie z konstytucją Sąd Najwyższy sprawował nadzór nad orzecznictwem wszystkich sądów, ustalając wytyczne wymiaru sprawiedliwości i praktyki sądowej. Funkcja sędziego Sądu Najwyższego, na którą powoływała się Rada Państwa po zasięgnięciu opinii, była kadencyjna. Dawało to możliwość wymiany sędziów, który nie spełniali pokładanych w nich nadziei, a przedłużenia pracy tym, którzy się sprawdzili. W ten sposób tworzono system nacisku i korumpowania sędziów, uzależniając ich dalszą karierę na stanowisku od skłonności do współpracy. Co więcej, liczba sędziów SN nie była uregulowana, zawsze więc można było powołać w jej grono nową osobę, bardziej „otwartą" na współpracę ${ }^{31}$. O tym, jak w praktyce wyglądały zalecenia personalne, można przeczytać np. w „Informacji o działalności Sądu Najwyższego w kadencji 1972-1977” przesłanej przez Wydział Administracyjny KC do przewodniczącego Rady Państwa PRL Henryka Jabłońskiego. Dokument ten zawierał ocenę działalności poszczególnych sędziów i sugestie kadrowe. Na przykład Wydział Administracyjny „nie proponował” do składu sędziowskiego Franciszka Wróblewskiego, od 1962 do 1975 r. pełniącego funkcję prezesa Izby Karnej Sądu Najwyższego. Został on z niej zwolniony, bo „nie zapewnił należytego kierowania pracami Izby jak też oddziaływania na sędziów. W orzecznictwie Izby Karnej w latach 1972-1974 wystąpiły tendencje sprzeczne z programem Biura Politycznego i uchwałami Rady Państwa”. Wynika z tego, że sędzia Wróblewski nie umiał lub nie chciał skłonić podległych sędziów do orzekania zgodnie z linią polityczną wyznaczoną przez Biuro Polityczne KC PZPR. W tym kontekście interesująco brzmi opinia o Bogdanie Dzięciole (w 1982 r. w „zespole” do spraw ,jedenastki”), którego określono jako sędziego o wysokich kwalifikacjach i „umiejętności kierowania zespołami ludzi”. Franciszek Rusek (jako urzędnik Ministerstwa Sprawiedliwości brał udział w 1968 r. w naradzie ,zespołu” do spraw politycznych prowadzonej przez Moczara, w 1982 r. brał udział w ustalaniu strategii oskarżenia ,jedenastki”): „Potrafi umiejętnie kierować dużymi zespołami ludzi i wyzwalać ich inicjatywę. Jego duże doświadczenie w pracy społecznej i politycznej dają rękojmię należytego kierowania pracami”. Kazimierz Lipiński (w 1982 r. w ,zespole” do spraw ,jedenastki”): „Pracowity i wnikliwy. Dobrze kieruje pracami Izby Wojskowej. Posiada wysoki autorytet i szacunek" "32. Sędzia Roman Kryże, który w 1965 r. skazywał w procesie ,afery mięsnej”, był w latach 1955-1977 sędzią Sądu Najwyższego. Na potrzeby tej sprawy został specjalnie delegowany, gdyż zapewne gwarantował odpowiedni wyrok. Prof. Andrzej Zoll, który przyznaje, że ,podczas obrad Okrągłego Stołu trochę naiwnie zakładaliśmy, że [...] sędziowie sami się zweryfikują", wspomina, iż Izba Karna Sądu Najwyższego była tak skompromitowana, że usunięto prawie cały skład — spośród trzydziestu sędziów po weryfikacji zostało trzech.

\footnotetext{
${ }^{31}$ A. Rzepliński, Sądownictwo w PRL, Londyn 1990, s. 77.

32 AAN, KC PZPR, LI/35, Informacja o działalności Sądu Najwyższego w kadencji 1972-1977 wraz z załącznikiem, V 1977, b.p.
} 
Drugim ogniwem systemu było Ministerstwo Sprawiedliwości. Zgodnie z przepisami sędziego można było ukarać za niepodporządkowanie się poleceniom wydanym przez prezesa sądu, urzędnika z Ministerstwa Sprawiedliwości czy samego ministra. Niewygodnego sędziego orzekającego można było wymienić, co planowano zrobić np. w czasie procesu KPN. Bardziej subtelną metodą było zastosowanie nacisków. Wizytatorzy sądów wyższych lub Ministerstwa Sprawiedliwości mieli możliwość wglądu w prace sędziego. Jak opisał to Andrzej Rzepliński: „Nawet gdyby pragnęli oni kontemplować jedynie elegancję wszywania w akta kolejnych kart toczącej się sprawy, jest oczywiste, iż sędzia rozpoznający tę sprawę zada sobie pytanie, jakie prowadzenie jej i orzeczenie usatysfakcjonowałoby wizytatora [...] W pewnych sprawach przed osobistą interwencją telefoniczną nie cofa się nawet minister sprawiedliwości lub jego zastępcy. Wywiera to na pewno silne wrażenie na sędzim, zwłaszcza młodym i pracującym w sądzie prowincjonalnym"33.

System doboru sędziów oraz ich awansowania, nie tylko na tak wysokim szczeblu jak Sąd Najwyższy, był nastawiony na kreowanie oraz promowanie tzw. sędziów dyspozycyjnych. Taki sędzia ,nie zawodzi pokładanej w nim przez administrację sądową lub czynniki stojące poza sądem nadziei”34. Taka postawa była niemal cnotą sędziego - Andrzej Rzepliński przytoczył passus pracy naukowej przedstawiający aprobująco następującą sytuację: „Nie mógł być prezesem sądu ten, kto nie gwarantował takiego orzecznictwa, które byłoby akceptowane przez czynniki decydenckie, reprezentujące system władzy"35.

Nie ma bezpośredniego dowodu na to, że w wyżej opisanych procesach politycznych opinia KC PZPR czy też „,zespołów” wpływała na wyrok wydawany przez sędziów. Jednak z tego punktu widzenia casus procesu członków KPN w latach 1980-1981 jest bardzo ciekawy, ponieważ w jego „ręcznym sterowaniu” pojawiają się problemy, z którymi władze nie stykały się w latach 1964, 1968, 1969, 1971 czy 1976. W dokumentach MSW oraz KC PZPR po raz pierwszy znajdujemy wyraz niepewności co do zachowania sędziów. W latach wcześniejszych sprawa ta nie pojawia się w ogóle lub była traktowana marginesowo. Zazwyczaj nie pojawiały się wątpliwości, czy wyrok będzie zgodne z oczekiwaniami.

Rok 1980 był przełomowy w systemie działania sądownictwa. NSZZ „Solidarność” od powstania coraz głośniej mówiła o praworządności jako gwarancji prawidłowego funkcjonowania państwa. Do związków zawodowych zaczęli zapisywać się także sędziowie. Chociaż trudno oszacować ich liczebność, rachunki wahają się od $838^{36}$ do około tysiąca sędziów ${ }^{37}$. Do NSZZ Pracowników Wymiaru Sprawiedliwości „Solidarność” należeli przeważnie sędziowie z krótszym stażem. Ówczesny wiceminister sprawiedliwości Tadeusz Skóra thumaczył, że „najbardziej zaniepokojona jest ta część kadry, która stanowi [...] starszą kadrę sędziów. Natomiast cała kadra młodsza, co chyba jest charakterystyczne w ogóle dla kadry, jest zaangażowana w sądownictwie w działalność «Solidarności» i powiedzmy 1/4 sędziów należy do «Solidarności» i nastroje ogólnie «Solidarności» udzielają się tej części kadry”38. Prawnicza „Solidarność” domagała się szeroko zakrojonych refom, a nawet przeprowadzenia weryfikacji środowiska.

\footnotetext{
${ }_{33}$ A. Rzepliński, Sądownictwo w PRL, s. 67.

${ }^{34}$ Ibidem, s. 66.

${ }^{35}$ Ibidem, s. 71, 72.

${ }^{36}$ AAN, Ministerstwo Sprawiedliwości, 7/186, Referat ministra sprawiedliwości Sylwestra Zawadzkiego na konferencji prezesów sądów wojewódzkich oraz okręgowych sądów pracy i ubezpieczeń społecznych z udziałem I sekretarzy POP w Popowie 12-13 III 1982 r., k. 8.

37 A. Strzembosz, M. Stanowska, Sędziowie warszawscy w czasie próby 1981-1988, Warszawa 2005, s. 60,61 .

${ }^{38}$ Archiwum Rady Ministrów Kancelarii Prezesa Rady Ministrów, Stenogram posiedzenia prezydium rządu, 14 V 1981 r., k. 22
} 
Takie żądania padały w czasie rozmów o planowanych zmianach w funkcjonowaniu wymiaru sprawiedliwości prowadzonych w 1981 r. z ministrem sprawiedliwości Jerzym Bafią. Adam Strzembosz, sędzia i członek kierownictwa prawniczej „Solidarności”, wyjaśnił, że w postulacie tym ,chodzi o sędziów, którzy specjalizują się w orzekaniu w sprawach pewnego typu”, i podkreślał, że należy „zbadać zarzuty wysuwane przeciwko sędziom”. Bafia tłumaczył, że takie twierdzenia „to namawianie do złamania zasady niezawisłości sędziów”, jednak czuł potrzebę usprawiedliwienia patologii działania systemu: „Były różne lata i różne sytuacje. Odnowy nie można zaczynać od wyrzucania ludzi za popełnione błędy" — tłumaczył. Wobec ponawiania żądań o przeprowadzenie weryfikacji Bafia zaczął powtarzać twierdzenia o „zamachu na niezawisłość sędziowską” i „polowaniu na czarownice”. Adam Strzembosz konkludował, że brak jest mechanizmów zabezpieczających niezawisłość sędziowską, a „są sędziowie, których wyroki są łamaniem prawa [...] nie chodzi o pomyłki [...] [oni] «mylili się» nagminnie" 39 .

Niezależnie od skutków rozmów z ministrem działalność „Solidarności” wytworzyła atmosferę, która pozwoliła sędziom na walkę o swoje prawa, umacnianie samorządu sędziowskiego i niezależności. Przykład sprawy KPN prowadzonej w 1980 i 1981 r. pokazuje, że funkcjonujący przez lata system „niewidzialnego” kierowania pracą wymiaru sprawiedliwości okazał się mało skuteczny w sytuacji, kiedy sędziowie powołali własny związek zawodowy i otwarcie zaczęli mówić o patologiach systemu, naruszaniu zasady niezawisłości i niezależności sędziego oraz o „sędziach dyspozycyjnych”.

Zmiana w systemie wymiaru sprawiedliwości została dokonana po wprowadzeniu stanu wojennego, kiedy przystąpiono do weryfikacji kadry sędziowskiej. Rada Państwa odwołała dwudziestu sześciu sędziów, co najmniej siedmiu odwołano z zajmowanych stanowisk kierowniczych, a jedenastu zrezygnowało ,ze względu na przekonania polityczne”, kolejni zdecydowali się przejść na emeryturę lub do palestry ${ }^{40}$. W lutym 1982 r. minister sprawiedliwości Sylwester Zawadzki tłumaczył na posiedzeniu Komisji Prawa i Praworządności KC PZPR, że „Solidarność wyrządziła istotne szkody wymiarowi sprawiedliwości [...] nastąpiło zwichrzenie w świadomości sędziów".

Dobitnie o problemach władz występujących w roku 1981 mówił Bogdan Dzięcioł. Warto przytoczyć tu passusy z jego wystąpienia, gdyż ten prezes Sadu Najwyższego, piętnując praktyki z lat 1980-1981, opisuje, jaki powinien być idealny wymiar sprawiedliwości PRL: „Nadzór nad sądami [...] był częstokroć iluzoryczny: Ministerstwo Sprawiedliwości i Sąd Najwyższy napotykały na określone trudności w ukierunkowaniu polityki orzeczniczej; kształtowała się ona żywiołowo [...] Inne zjawisko, to zaskakująca reakcja sądów w postaci generalnego złagodzenia represji [...] Czyżby nastąpiło tu sprzeniewierzenie się sędziów? Należy na to pytanie odpowiedzieć: ogółu sędziów nie, ale części sędziów tak!". Jako motto można wręcz potraktować fragment $\mathrm{z}$ jego wypowiedzi: „Wiele jest sposobów doskonalenia orzecznictwa sądowego, ale najpilniejszą, kluczową sprawą jest rozwiązanie nabrzmiałych problemów kadrowych. Stara prawda głosi, my sędziowie to pamiętamy, że właściwa polityka kadrowa stanowi istotną

\footnotetext{
${ }^{39}$ AS „Biuletyn Pism Związkowych i Zakładowych”, nr 13, 22 IV-26 IV 1981, k. 207-209.

${ }^{40}$ AAN, KC PZPR, LI/39, Wykaz sędziów odwołanych przez Radę Państwa, 27 II 1982, b.p.; ibidem, Wykaz sędziów odwołanych z kierowniczych funkcji przez ministra sprawiedliwości w okresie stanu wojennego, 27 II 1982, b.p.; AAN, Ministerstwo Sprawiedliwości, 7/536, Notatka w sprawie kadry sędziowskiej na dzień 27 stycznia 1982 r., k. 8-9. Por. Notatka pracownika Gabinetu Ministra Sprawiedliwości Romana Ziółkowskiego na temat odwołań i zwolnień sędziów i asesorów sądowych w ramach akcji weryfikacyjnej pracowników wymiaru sprawiedliwości, w: Stan wojenny $w$ dokumentach władz PRL (1980-1983), wybór, wstęp i oprac. B. Kopka, G. Majchrzak, Warszawa 2001, s. 176, 177.
} 
gwarancję prawidłowości orzecznictwa i pełnej niezawisłości sędziowskiej. Wniosek z tego konkretny: sędzia, który świadomie nie realizuje linii partii i nie przestrzega obowiązującego prawa, w tym dekretów stanu wojennego, winien być niezwłocznie odwołany" ${ }^{\natural 1}$.

W przywracaniu przez władze pożądanego stanu w sądownictwie nieoceniona była rola Sądu Najwyższego i Ministerstwa Sprawiedliwości. Mirosław Milewski miał przedstawić na posiedzeniu Biura Politycznego wnioski płynące z doświadczeń stanu wojennego: „Sąd Najwyższy jako naczelny organ sądowy sprawuje konstytucyjny nadzór nad działalnością orzeczniczą wszystkich sądów, a więc nad najważniejszą z punktu widzenia praworządności formą stosowania i rozumienia prawa, w szczególnie trudnych i złożonych warunkach społeczno-politycznych. Sąd Najwyższy właściwie spełniał swą konstytucyjną rolę kontynuując ustabilizowaną linię orzecznictwa. Np. decyzje Sądu Najwyższego w sprawie przeciwko kierownictwu KPN udaremniły próby storpedowania tego procesu prowadzonego w sądzie warszawskim w sposób urągający powadze sądu, pozwalający oskarżonym na uprawianie na sali rozpraw agitacji antysocjalistycznej”. Po wprowadzeniu stanu wojennego Sąd Najwyższy podjął wiele uchwał dotyczących wykładni nowego ustawodawstwa i korygujących wadliwe ich zdaniem orzeczenia sądowe ${ }^{42}$.

\section{Podsumowanie}

Można stwierdzić, że po 1964 r. wykształciła się praktyka sprawowania przez KC PZPR nadzoru nad szczególnie ważnymi sprawami karnymi. W pierwszej kolejności MSW wespół z Prokuraturą zbierały odpowiedni materiał dowodowy i szykowały wstępny scenariusz oskarżenia. Na końcowym etapie prac te pomysły przedstawiano pod dyskusję powołanemu „,zespołowi”. Gremium takie nie było ciałem wyłanianym formalnie przez żaden organ partyjny. Na jego czele stał najczęściej członek Biura Politycznego odpowiedzialny za nadzór nad służbami specjalnymi. Istotną rolę odgrywał zawsze Wydział Administracyjny KC, który odpowiedzialny był za partyjną kontrolę m.in. bezpieczeństwa publicznego i sądownictwa. Na posiedzeniach pojawiali się wysocy przedstawiciele MSW oraz Prokuratury Generalnej. Rzadziej pojawiali się przedstawiciele Sądu Najwyższego oraz Ministerstwa Sprawiedliwości. Zespoły takie były odpowiedzialne za to, aby wniesione oskarżenie uwzględniało sytuację społeczno-polityczną i ewentualne polityczne reperkusje. W ich pracy dostrzegalna jest tendencja do „zawężania” aktu oskarżenia. MSW i Prokuratura przedstawiały obszerną paletę zarzutów, które następnie pod wpływem kierownictwa partyjnego były ograniczane. W trakcie posiedzeń podejmowano także decyzje odnośnie do terminów wniesienia aktu oskarżenia oraz liczby osób nim objętych. Tutaj, podobnie jak w przypadku kwalifikacji prawnej, czynniki polityczne dążyły na ogół do ograniczenia liczby oskarżonych. Można pokusić się o stwierdzenie, że zazwyczaj kierownictwo partyjne chciało, żeby akt oskarżenia gwarantował sprawne przeprowadzenie sprawy w możliwie krótkim czasie. Można założyć, że spotkania zespołów pozwalały na skoordynowanie akcji oraz stworzenie wspólnej strategii działania odpowiednich wydziałów KC, MSW oraz Prokuratury Generalnej. Kwestia ostatniego ogniwa, sędziów orzekających w sprawach politycznych, była zapewne regulowana poprzez przydzielanie do tychże spraw osób określanych mianem „dyspozycyjnych” oraz odpowiednie sugestie i naciski ze strony Ministerstwa Sprawiedliwości oraz Sądu Najwyższego.

\footnotetext{
${ }^{41}$ AAN, KC PZPR, LI/119, Protokół z posiedzenia Komisji Prawa i Praworządności KC PZPR w dniu 13 II 1982, k. 4-30.

${ }^{42}$ AAN, LI/42, Ocena działalności organów ścigania i wymiaru sprawiedliwości, grudzień 1983, k. 9.
} 


\section{Political Steering of the Administration of Justice in People's Poland until 1956. The Functioning of "Teams" Dealing with Political Trials in 1964-1982}

This article describes the mechanism of the impact exerted by Party authorities upon the form, course, and outcome of numerous political trials conducted after 1956. The presented findings are based on the results of an extensive survey carried out in the documentation of the Central Committee of the Polish United Workers' Party (CC PUWP), the General Prosecutor's Office of the People's Republic of Poland, the Ministry of Justice, the Ministry of Internal Affairs, and the Security Service. Preserved documents makes it possible to prove and characterise Party influence upon trials involving several most important political cases during the 1964-1982 period: the trials of Kuron and Modzelewski, the student opposition Komandosi and Taternicy, the conspiratorial Ruch organisation, KSS-KOR (Social Self-defence Committee - KOR/ Workers Defence Committee/), KPN (Confederation for an Independent Poland), and the socalled Jedenastka, i.e. the leaders of "Solidarity" and chief advisers of the trade unions members of the democratic opposition. The analysed sources testify that the ultimate shape of the indictments and the course of a given trial were established during meetings held by a small group, often described as a "team". Such "team" sessions were attended by representatives of the CC PUWP (the Administration Department of the CC), the Prosecutor's Office, the Ministry of the Interior, and often the representatives of the Ministry of Justice or even the Supreme Court. Much indicates that these solutions functioned for years to come and were of a systemic character. They guaranteed taking into account the political interests of the Political Bureau and a matching staging of the trials' course. 